\title{
Enhancement of growth, defense response in brinjal and inhibitory potential of salicylic acid against Fusarium oxysporum f. sp. melongenae
}

\author{
BANU NAZIYA* and M.S. SHARADA \\ Department of Studies in Botany, University of Mysore, Manasagangotri, Mysore 570 006, Karnataka, India
}

Received: 10 May 2017/ Accepted: 18 July 2017/ Published online: 24 July 2017

(c) Indian Phytopathological Society 2017

\begin{abstract}
The study was carried out to evaluate the effects of salicylic acid in enhancement of growth, defense response and inhibition of colony growth of Fusarium oxysporum f. sp. melongenae under in vitro condition. The collected seed samples were primed with different concentrations of salicylic acid for $3 \mathrm{~h}$ to assess its effect on brinjal seed germination and seedling vigor using paper towel method. Inhibitory effect of salicylic acid was also tested against $F$. oxysporum $\mathrm{f}$. sp. melongenae using poisoned food technique. Hypersensitive response in salicylic acid treated seedlings was also studied. Among salicylic acid treatments, $20 \mathrm{mM}$ for $3 \mathrm{~h}$ duration recorded maximum seed germination of $95 \%$ and seedling vigour of $\mathbf{8 7 4 . 6}$ over non-treated control. In addition, the treatment also stood best in inhibiting mycelial growth of the pathogen under in vitro condition and showed enhanced hypersensitive response in treated seedlings. Thus, the study suggested that salicylic acid at $20 \mathrm{mM}$ concentration proved to be good in enhancement of seedling growth with significant inhibition of pathogen growth and also enhanced hypersensitive response in brinjal seedlings.
\end{abstract}

Keywords: Fusarium wilt disease, hypersensitive response, pathogen inhibition, seed germination and seedling vigour, Solanum melongena

Brinjal (Solanum melongena L.) is the most common vegetable crop grown in India. The crop is mainly cultivated for its fruit (purplish in color) which is used as a staple vegetable all over the world. The crop has also got nutritional and medicinal importance which makes it even more important in terms of cultivation, consumption and commercial purposes. The crop suffers from so many fungal diseases and wilt disease caused by Fusarium oxysporum f. sp. melongenae is common in occurrence which has resulted in severe loss in the productivity of brinjal (Altinok and Dikilitas, 2014). The disease control is cumbersome due to development of fungal resistance. Though chemical fungicides were being applied to manage the disease but these fungicides have adverse effects on soil microflora and environment. Management of plant diseases through induction of resistance is rising. Plants have their own defensive system but sometimes when pathogen is virulent, plants known to get affected by diseases. In such circumstances inducing resistance by artificial means using inducers will be more beneficial and effective in enhancing the defensive capacity of the plant and also promoting plant growth respectively. Plant when comes in contact with pathogen known to produce hypersensitive cell death in the form of brown necrotic spots. This response can be increased with the inducer treatments. Inducer like salicylic acid is appearing to be auspicious in management of fungal diseases due to its

${ }^{*}$ Corresponding author: naziyauom @ gmail.com ecofriendly nature (Ali et al., 2009). The reports on bioagents, organic amendments, chemical, microbial and soil amendments have been used to control/ manage the diseases in brinjal (Haseeb and Kumar, 2007; Lal et al., 2017). The work on salicylic acid mediated resistance and enhancement of growth against Fusarium wilt of brinjal has not yet been carried out so far. Therefore, the present study was undertaken to evaluate the effect of different concentrations of salicylic acid in enhancement of seedling growth, defense response and inhibition of mycelial growth of F. oxysporum f. sp. melongenae under in vitro conditions.

Susceptible seed samples of Solanum melongena $\mathrm{cv}$. Dhenu were collected from different agricultural farms, local seed agencies and APMC of Mysore district. $F$. oxysporum f. sp. melongenae (FOM) causative agent of wilt disease was isolated from the infected brinjal plant.

Salicylic acid (SA) was prepared in different concentrations of $10 \mathrm{mM}, 20 \mathrm{mM}, 40 \mathrm{mM}$ and $80 \mathrm{mM}$ by dissolving $0.138 \mathrm{~g}, 0.276 \mathrm{~g}, 0.552 \mathrm{~g}$ and $1.049 \mathrm{~g}$ of SA with distilled water and the final volume of each solution was made up to $100 \mathrm{~mL}$.

Seed germination test was carried out by paper towel method. The different concentrations of SA treated and untreated brinjal seeds cv. Dhenu soaked for $3 \mathrm{~h}$ (four replicates of 100 seeds each) previously sterilized with 
$0.1 \%$ sodium hypochlorite for $2 \mathrm{~min}$, rinsed with sterile distilled water (SDW) were placed equidistantly on the moist germination sheets on which extra pre-soaked paper towel was placed, rolled and incubated at $25 \pm$ $2^{\circ} \mathrm{C}$ for fourteen days. At fourteen days, seed germination and seedling vigour was calculated (Abdul Baki and Anderson, 1973).

Percent germination $(P G)=\frac{\text { Number of seeds germinated }}{\text { Total number of seeds plated }}$

Vigour Index = (Mean root length + Mean Shoot length) $\times$ Percent germination

About $2 \mathrm{~mm}$ FOM mycelia was aseptically inoculated to the center of the PDA plates previously amended with 2 $\mathrm{ml}$ of $10 \mathrm{mM}, 20 \mathrm{mM}, 40 \mathrm{mM}$ and $80 \mathrm{mM}$ concentrations of SA and the plate containing simple PDA media served as control. All the plates were incubated at $25 \pm 2^{\circ} \mathrm{C}$ for seven days and then the fungal colony diameter in all concentrations of SA was measured. The experiment was repeated thrice. Percent growth inhibition (PGI) was calculated by the formula of Mishra et al. (2005).

HR was carried out in sampled seedlings of brinjal by modifying the method of Kumudini et al. (2001). The SA treated seedlings inoculated with pathogen and nontreated inoculated seedlings of brinjal were observed at 24 hours after inoculation (h.a.i.) for the external appearance of necrotic streaks on the treated seedlings. Each treatment consisted of four replicates of 25 seedlings and was repeated thrice.

Seeds treated with different concentrations of SA (10 mM, $20 \mathrm{mM}, 40 \mathrm{mM}$ and $80 \mathrm{mM}$ ) for $3 \mathrm{~h}$ duration showed enhanced seed germination and seedling vigour in comparison to non-treated control. Among the different concentrations of SA tested, $20 \mathrm{mM}$ concentration for $3 \mathrm{~h}$ duration recorded the highest seed germination and seedling vigor followed by $40 \mathrm{mM} \mathrm{SA}$. The minimum seed germination and seedling vigor was recorded at $10 \mathrm{mM}$ SA. The untreated control seedlings showed seed germination of $69.5 \%$ and seedling vigour of 416.5 (Table 1). Similar observations of SA seed treatment at two different concentrations ( $5 \mathrm{mM}$ and $1 \mathrm{mM}$ ) enhanced seed germination and seedling vigor in wheat plants (Dolatabadian et al., 2009).

The efficiency of SA in inhibiting the colony growth of the FOM under in vitro conditions was also tested in the present study and the results indicated that SA reduces the growth of the FOM at very significant level. Among the salicylic acid treatments, the maximum growth inhibition was noticed at $20 \mathrm{mM}$ concentration followed by $40 \mathrm{mM}$ and $80 \mathrm{mM}$ SA. The minimum growth inhibition was noticed at $10 \mathrm{mM} \mathrm{SA}$ (Table 1, Fig. 1). The parallel study on inhibitory effect of SA reported to exhibit good antifungal activity against Colletotrichum orbiculare and Phytophthora capsici (Park et al., 2007). The present study also reported to increase the hypersensitive response in SA treated inoculated brinjal seedlings when compared to non-treated control inoculated seedlings at 24 h.a.i. The maximum appearance of $\mathrm{HR}(72.3 \%)$ was noticed in $20 \mathrm{mM}$ SA treated inoculated seedlings followed by $63 \% \mathrm{HR}$ response in $40 \mathrm{mM}$ SA treated inoculated seedlings and the susceptible inoculated control seedlings recorded poor $\mathrm{HR}$ of $13 \%$ at the same time interval (Fig. 2). Similarly, pretreatments with Acibenzolar-S-methyl induced hypersensitive reaction in brinjal plants (Altinok and Dikilitas, 2014).

The significance of the study includes, salicylic acid which is one of the important biochemical elicitor gaining attention due to its unique properties in enhancement of

Table 1. Effect of salicylic acid treatments on brinjal seed germination and seedling vigour at $3 \mathrm{~h}$ duration and its inhibition potential against FOM under in vitro conditions

\begin{tabular}{lccccc}
\hline Elicitor/inducer & $\begin{array}{c}\text { Concentration/ } \\
\text { control }\end{array}$ & $\begin{array}{c}\text { \% seed } \\
\text { germination }\end{array}$ & $\begin{array}{c}\text { Seedling } \\
\text { vigour index }\end{array}$ & $\begin{array}{c}\text { Colony } \\
\text { diameter (mm) }\end{array}$ & $\begin{array}{c}\text { Percent growth } \\
\text { inhibition (PGI) }\end{array}$ \\
\hline \multirow{3}{*}{ Salicylic acid } & Control (SDW) & 69.5 & 416.5 & 9.00 & - \\
& $10 \mathrm{mM}$ & 51.3 & 244.0 & 6.33 & $29.6 \%$ \\
& $20 \mathrm{mM}$ & 95.0 & 874.6 & 2.05 & $77.2 \%$ \\
& $40 \mathrm{mM}$ & 85.0 & 633.0 & 3.49 & $61.2 \%$ \\
& $80 \mathrm{mM}$ & 78.3 & 514.5 & 4.73 & $47.4 \%$ \\
\hline
\end{tabular}

Each value is a mean of four replicates (\% germination and vigour) and three replicates (PGI). The values are separated by Tukey HSD (One way Anova ver. 11.5)
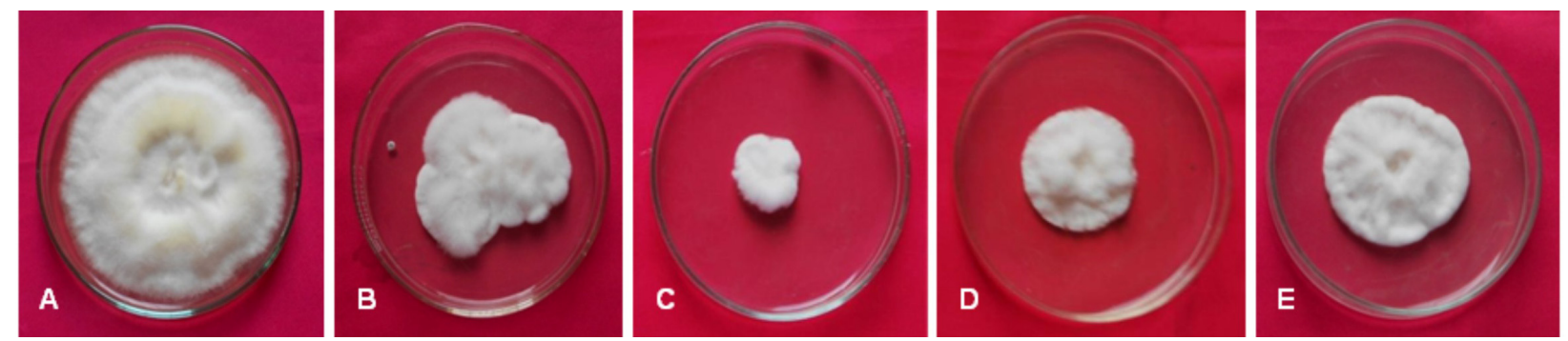

Fig. 1. Effect of salicylic acid treatments on mycelial growth inhibition of FOM (A-Control, B-10 mM SA, C- 20 mM SA, D- 40 mM SA, E$80 \mathrm{mM} \mathrm{SA})$ 


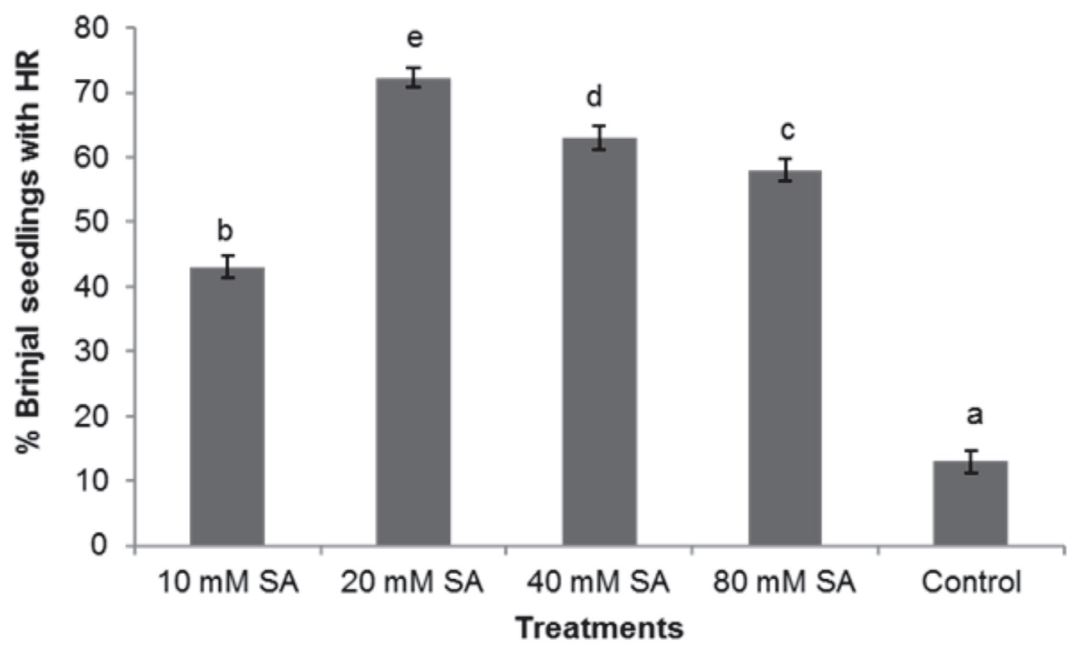

Fig. 2. Hypersensitive reaction (HR) in salicylic acid treated brinjal seedlings inoculated with FOM at 24 h.a.i. Each value is the mean of three replicates and bars sharing different letters are significantly different $(p \leq 0.05)$ according to Tukey's HSD (honest significant difference). The vertical bars indicates the standard errors

defense mechanism in plants against disease causing micro-organisms. In the present study, low concentration of salicylic acid particularly $20 \mathrm{mM}$ was found to be efficient over non-treated control. SA can be used as potential inducer in plant growth promotion and defense response in brinjal.

\section{ACKNOWLEDGEMENTS}

The authors are thankful to Department of Studies in Botany, DST-FIST and University of Mysore, Manasagangotri, Mysore for giving all the necessary facilities to carry out the research.

\section{REFERENCES}

Abdul-Baki and Anderson JD (1973). Vigour determination in soybean seed by multiple criteria. Crop Sci. 13: 630-633.

Ali AA, Ghoneem KM, El-Metwally MA and Abd EHKM (2009). Induce systemic resistance in lupine against root rot diseases. Pak. J. Biol. Sci. 12: 213-221.

Altinok $\mathrm{H}$ and Dikilitas M (2014). Antioxydant response to biotic and abiotic inducers for the resistance against Fusarium wilt disease in eggplant (Solanum melongena L.). Acta Bot. Croat. 73: 79-92.
Dolatabadian A, Modarres Sanavy SAM and Sharifi M (2009). Effect of salicylic acid and salt on wheat seed germination. Acta Agric. Scand., Sect. B. 59: 456-464.

Haseeb A and Kumar V (2007). Efficacy of bioagents and organic amendment materials against Fusarium oxysporum causing brinjal wilt. Indian Phytopath. 60: 108111.

Kumudini BS, Vasanthi NS and Shetty HS (2001). Hypersensitive response, cell death and histochemical localization of hydrogen peroxide in host and non host seedlings infected with the downy mildew pathogen Sclerospora graminicola. Ann. Appl. Biol. 139: 217-225.

Lal HC, Radha M, Praveen K, Savita E, Binay K and Niraj K (2017). Management of wilt complex in brinjal using chemical, biocontrol agent and soil amendment alone and in combinations. Indian Phytopath. 70: 220-223.

Mishra BD, Sahoo KC, Ghose S and Rout MK (2005). In vitro evaluation of plant extracts, oilcakes and agrochemicals against web blight of green gram caused by Rhizoctonia solani. J. Mycopathol. Res. 43: 255-257.

Park CN, Lee D, Kim W, Hong Y, Ahn JS and Kim BS (2007). Antifungal activity of salaceyin-A against Colletotrichum orbiculare and Phytophthora capsici. J. Basic Microbiol. 47: 332-339. 